\title{
Implication of nitric oxide in the pathogenesis of influenza virus infection
}

\author{
Birutè Zablockienė $\dot{e}^{1 *}$, \\ Arvydas Ambrozaitis ${ }^{1}$, \\ Tomas Kačergius ${ }^{2}$, \\ Stefan Gravenstein ${ }^{3}$ \\ ${ }^{1}$ Department of Infectious, \\ Chest Diseases, Dermatovenerology \\ and Allergology, Faculty of Medicine, \\ Vilnius University, Lithuania \\ ${ }^{2}$ Department of Physiology, Biochemistry, \\ Microbiology and Laboratory Medicine, \\ Faculty of Medicine, \\ Vilnius University, Lithuania \\ ${ }^{3}$ Departments of Medicine, \\ The Warren Alpert Medical School, \\ and Health Services and Practice \\ of Brown University, USA
}

Influenza continues to be a significant threat to global public health. Even annual vaccination fails to prevent complicated illness and death. The findings in various studies suggest that severe disease is attributed to pulmonary complications - primary viral and secondary bacterial pneumonia. A number of investigations on influenza virus infection in the mouse model demonstrate that overproduction of free radicals, including nitric oxide (NO), contributes to the development of pneumonia during influenza virus infection. The role of NO on influenza virus infection in mice and differences between inducible nitric oxide synthase activation in mouse and human systems are discussed in this review. The biosynthesis of NO, mechanisms for regulation of NO production, nitrative stress during pathogenesis of various microbial infections are overviewed as well.

Key words: influenza virus infection, nitric oxide, inducible nitric oxide synthase

\section{INTRODUCTION}

Influenza, in its zoonotic, seasonal epidemic and pandemic forms, causes a substantial impact on global public health. Every year, an estimated 500,000 deaths worldwide, both of very young children, but mostly older adults, are attributed to seasonal influenza virus infections (World Health Organization, 2009). The past 100 years have

*Corresponding author. E-mail: biruterockaite@yahoo.com seen four influenza pandemics: H1N1 in 1918, H2N2 in 1957, H3N2 in 1962, and H1N1 in 2009 (Simonsen et al., 1998; Bautista et al., 2010). With each pandemic came a spike in hospitalization and death rates in addition to a higher proportion of deaths in people under the age of 65 , although the relative impact varied widely with the different viruses (Simonsen et al., 1998; Belongia et al., 2010). On May 28, 2010 worldwide more than 214 countries and overseas territories or communities have reported laboratory confirmed cases of pandemic 
influenza H1N1 2009, including over 18,114 deaths (Belongia et al., 2010).

Although pandemic and seasonal influenza usually cause self-limited illnesses, a small percentage of cases are fatal (Taubenberger, Morens, 2008). The findings in various studies suggest that severe disease is associated with the development of influenza viral pneumonia (Taubenberger, Morens, 2008; Gill et al., 2010; Morens et al., 2008; Mulder, Hers, 1972; Kuiken, Taubenberger, 2008), with or without secondary bacterial pneumonia (Morens et al., 2008; McCullers, 2008; Klugman et al., 2009). Influenza precedes outbreaks of certain bacterial infections, for example, pneumococcal or staphylococcal (Kuster et al., 2011; Tasher et al., 2011). Some of the pulmonary abnormalities of fatal influenza viral pneumonia might be induced by the release of host inflammatory mediators, rather than by a direct viral cytopathic effect (Kash et al., 2006; De Jong et al., 2006).

Results of mouse respiratory infection models clearly demonstrate the contribution of free radicals, including nitric oxide (NO), to the development of acute lung inflammation and mouse mortality during the viral infection (Akaike et al., 1996; 2003; Ricciardolo, 2003; Xiong et al., 1999; Karupiah et al., 1998; Domachovske et al., 2001; Suliman et al., 2001; Shanley et al., 2002).

\section{Biosynthesis of nitric oxide}

In the respiratory tract, $\mathrm{NO}$ is produced by a wide variety of cell types, including epithelial cells, airway nerves, inflammatory cells (monocytes, macrophages, neutrophils, mast cells) and vascular endothelial cells (Ricciardolo, 2003; Barnes, Belvisi, 1993). NO is synthesized from $L$-arginine in a reaction catalyzed by a family of nitric oxide synthase (NOS) enzymes. Conversion of L-arginine to $\mathrm{NO}$ and $\mathrm{L}$-citrulline requires also nicotinamide adenine dinucleotide phosphate (NADPH) and oxygen $\left(\mathrm{O}_{2}\right)$ as co-substrates and tetrahydrobiopterin $\left(\mathrm{BH}_{4}\right)$, flavin adenine dinucleotide (FAD), flavin mononucleotide (FMN) and iron (heme) as cofactors (Ricciardolo, 2003; Hobbs, Ignarro, 1997). The NOS is structurally divided into two major domains, the reductase and oxygenase domains (Ricciardolo, 2003; Marletta, 1993). Calmodulin couples these domains and transfers electrons between flavins and the heme moiety (Ricciardolo, 2003; Abu-Soud, Stuehr, 1993).
The NOS exists in three distinct isoforms. Constitutive neural NOS (nNOS or NOS I) is predominantly expressed within neurons in brain and peripheral nervous system. Constitutive endothelial NOS (eNOS or NOS III) is mainly expressed in endothelial cells (Ricciardolo, 2003; Förstermann et al., 1991). Increase in free intracellular calcium concentration $\left(\left[\mathrm{Ca}^{2+}\right]\right)$ stabilizes the binding of calmodulin to eNOS and nNOS, and activates the enzyme to produce NO. NO production by constitutively expressed NOSs is transient and short lasting (Ricciardolo, 2003; Förstermann et al., 1991; Korhonen et al., 2005).

The third isoform of NOS family is the inducible NOS (iNOS, NOS II). Exposure to microbial products such as lipopolysaccharide (LPS) and double stranded (ds) RNA or proinflammatory cytokines induces the expression of iNOS gene in various inflammatory and tissue cells. Binding of calmodulin to iNOS is tight even at low $\left[\mathrm{Ca}^{2+}\right]$ and it can constantly produce high levels of $\mathrm{NO}$ for prolonged periods (Ricciardolo, 2003; Korhonen et al., 2005; Morris, Billiar, 1994; Bogdan, 2001).

\section{Regulation of inducible nitric oxide synthase ex- pression}

Human iNOS shares $80 \%$ homology to murine iNOS at the amino acid levels (Chartrain et al., 1994; Guo et al., 2006), but translation of the results describing the mechanisms of mouse iNOS expression to that of human is not always straightforward. The size of the iNOS promoter differs greatly between mouse $(\sim 1.5 \mathrm{~kb})$ and man (up to $16 \mathrm{~kb}$ ) (Lowenstein et al., 1993). Many mouse cells readily express iNOS in response to LPS or to a single cytokine, whereas human cells usually require a combination of different cytokines for detectable iNOS expression and NO synthesis (Korhonen et al., 2005). Unlike rodent mononuclear phagocytes and granulocytes, both human macrophages and monocytes do not release significant amounts of $\mathrm{NO}$ in vitro when stimulated with the classical iNOS inducers - interferon-gamma (IFN- $\gamma$ ) and lipopolysaccharide, although in vivo NO production during inflammatory processes seems evident (Muijsers et al., 2001). iNOS has been immunolocalized within the air way cells or human lung tissue that has been obtained from patients with acute respiratory distress syndrome, bacterial pneumonia, lung cancer, pulmonary sarcoidosis, idiopathic 
pulmonary fibrosis and asthma (Sittipunt et al., 2001; Tracey et al., 1994; Liu et al., 1998; Moodley et al., 1999; Saleh et al., 1997; Shiloh et al., 1999). Alveolar macrophages isolated from the lungs of patients with tuberculosis or acute respiratory distress syndrome (ARDS) following sepsis have been shown to express iNOS (Nicholson et al., 1996; Kobayashi et al., 1998). Uetani et al. (2000) in their study showed induction of iNOS gene expression in human airway epithelial cells by influenza A virus or synthetic dsRNA.

Despite the differences noted above, similarities exist between murine and human iNOS genes in terms of activating factors and conditions. The viral replication or viral components, bacterial LPS and cytokines, such as interleukin $1 \beta$ (IL- $1 \beta$ ), tumor necrosis factor $\alpha$ (TNF- $\alpha$ ), interferon $\alpha / \beta$ $($ IFN $-\alpha / \beta)$ and IFN- $\gamma$ can stimulate expression of the iNOS gene in both mouse and human cells during infectious processes. These inducers mediate the activation of cellular transcription factors - nuclear factor $\kappa \mathrm{B}(\mathrm{NF}-\kappa \mathrm{B})$, signal transducer and activator of transcription (STAT), interferon regulatory factor 1 (IRF-1), which, in turn, bind to their respective binding sites in the promoter region of iNOS gene and initiate transcription of the gene (Lowenstein et al., 1993; Taylor, Geller, 2000; Akaike, Maeda, 2000; Jacobs, Ignarro, 2001; Kačergius, Ambrozaitis, 2003).

The expression of iNOS is regulated at transcriptional and posttranscriptional levels (Turpeinen et al., 2011). LPS and IFN- $\gamma$ induce mouse iNOS promoter activity 50-100-fold (Lowenstein et al., 1993). Cytokine stimulation increases human iNOS promoter activity only approximately 7- to 10-fold, while mRNA expression increases more than 100-fold (Rodriguez-Pascual et al., 2000; De Vera et al., 1996). This demonstrates important differences in transcriptional and posttranscriptional regulation of iNOS expression between mouse and human cells (Turpeinen et al., 2011). Recent evidence supports the idea that regulation of iNOS mRNA stability is an important means to regulate iNOS expression. In the unstimulated macrophages and monocytes, nuclear run-on assays show continuous iNOS transcription, whereas human iNOS promoter constructs have basal activity (Korhonen et al., 2005). However, no iNOS mRNA or protein can be detected within the unstimulated macrophages and monocytes, indicat- ing the highly unstable nature of iNOS mRNA is highly unstable in these cells (Korhonen et al., 2005).

Role of nitric oxide during infections: molecular mechanisms of action

During microbial infections, excessive NO produced by iNOS has diverse functions ranging from antimicrobial and antiinflammatory host defense and cytoprotection to proinflamatory and cytotoxic activities (Zaki et al., 2005). The host defense function of NO is best characterized by antimicrobial and cytoprotective activities that have been observed in bacterial, fungal, and parasitic infections (Nathan, Hibbs, 1991; Doi et al., 1993; Umezawa et al., 1997; James, 1995). In contrast, NO-mediated inflammation and pathogenesis have been documented in several diseases including arthritis, encephalitis, ulcerative colitis, and viral infections (Akaike et al., 1996; Moncada et al., 1991; Nathan, Xie, 1994; Liew, 1995).

The chemical and biological reactivities of $\mathrm{NO}$ produced in inflamed tissues during infection or inflammation are greatly affected by concomitant production of oxygen radicals, particularly superoxide $\left(\mathrm{O}_{2}^{-}\right)$and hydrogen peroxide. The interaction of NO with reactive oxygen species causes formation of several reactive nitrogen oxides, such as peroxynitrite $\left(\mathrm{ONOO}^{-}\right)$and nitrogen dioxide $\left(\mathrm{NO}_{2}\right)$. Excessive peroxynitrite formation leads to the formation of nitrated proteins, inhibition of mitochondrial respiration, depletion of cellular energy, nucleic acid damage, apoptosis and necrotic cell death, resulting in cellular/tissue injury (Korhonen et al., 2005; Zaki et al., 2005; Szabo et al., 2007) (Figure).

3-Nitrotyrosine has been used as a marker of peroxynitrite formation and tissue injury. Tyrosine nitration is becoming increasingly recognized also as a functionally significant protein modification. Nitration of proteins and enzymes modulates their catalytic activity, cell signaling and cytoskeletal organization (Korhonen et al., 2005; Zaki et al., 2005; Szabo et al., 2007).

Another marker of nitrative stress during viral infections is 8-nitroguanosine, which is formed by nitration of guanosine by $\mathrm{ONOO}^{-}$or $\mathrm{NO}_{2}$ (Zaki et al., 2005). The first report of NO-dependent guanosine nitration during viral infection in vivo was provided in 2003 (Akaike et al., 2003). In that study, 


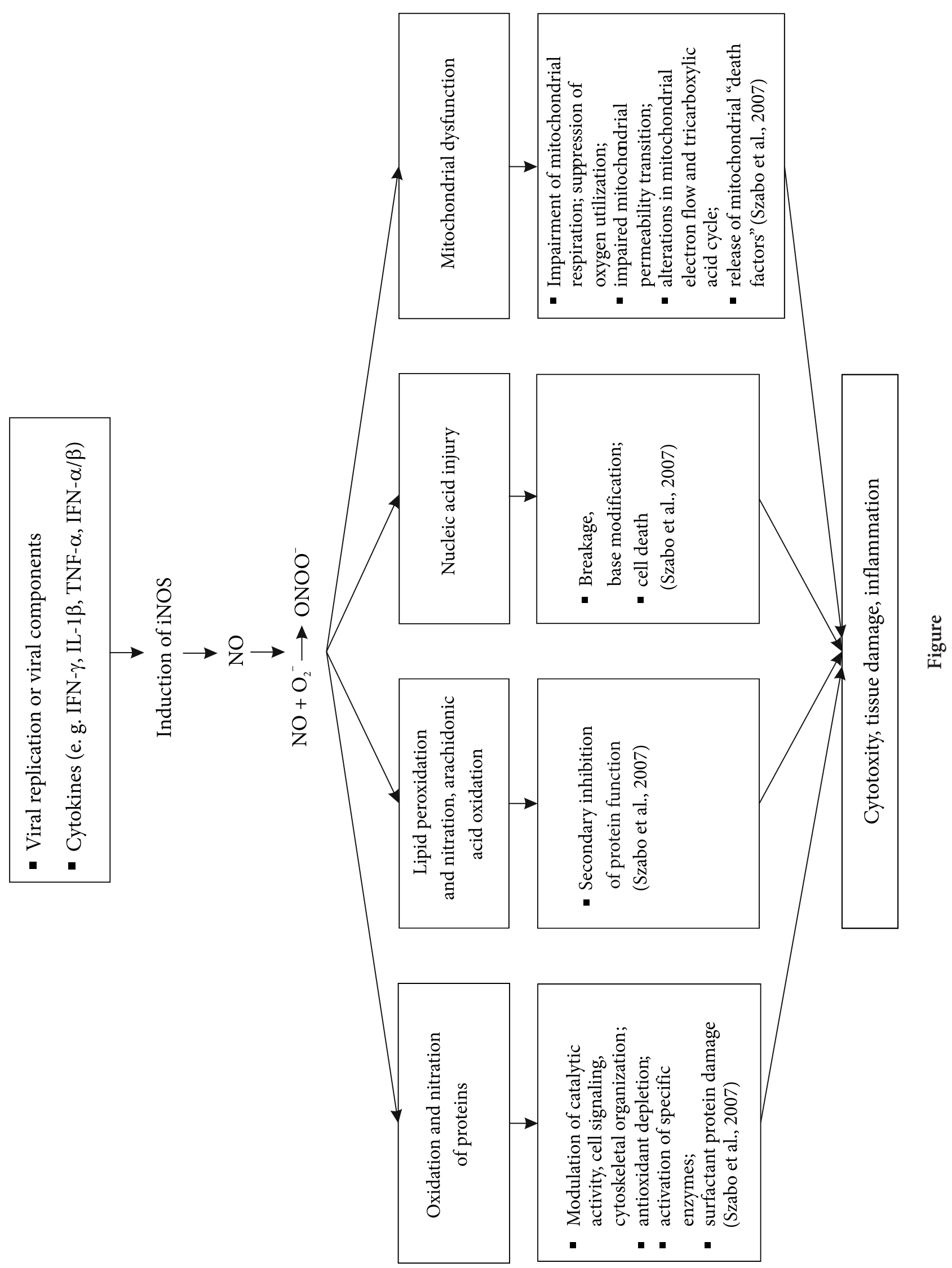


extensive 8-nitroguanosine formation in bronchial and bronchoalveolar epithelial cells during both influenza virus and Sendai virus infection was demonstrated. The 8-nitroguanosine formation correlated well with NO production and 3-nitrotyrosine generation. Contrariwise, 8-nitroguanosine staining was absent in the airways of $\mathrm{iNOS}^{-/-}$mice infected with influenza virus. In subsequent studies, certain unique features of 8-nitroguanosine were identified. This line of work established that 8-nitroguanosine has a potent redox-active property and mutagenic potential. Electron spin resonance (ESR) analysis determined that 8-nitroguanosine stimulated generation of $\mathrm{O}_{2}^{-}$from cytochrome P450 reductase and iNOS (Akaike et al., 2003; Sawa et al., 2003). This process is pathophysiologically significant because $\mathrm{O}_{2}^{-}$causes increased oxidative damage and $\mathrm{ONOO}^{-}$formation (Zaki et al., 2005).

$\mathrm{ONOO}^{-}$not only damages host tissues and cells in a nonselective manner, it also affects biomolecules of a host in a relatively selective fashion. For example, $\mathrm{ONOO}^{-}$activates matrix metalloproteinases (MMPs) - the enzymes that participate in the destruction of the extracellular matrix, which leads to tissue damage and remodeling (Okamoto et al., 2001; 2004). MMPs are also known to have a critical role in apoptosis induction (Okamoto et al., 2004). $\mathrm{ONOO}^{-}$readily inactivates both tissue inhibitor of MMP and a1-proteinase inhibitor, which is a major proteinase inhibitor in human plasma (Moreno, Pryor, 1992; Frears et al., 1996).

$\mathrm{ONOO}^{-}$also activates cyclooxygenase - the key enzyme for production of potent inflammatory prostaglandins (Landino et al., 1996). Thus, $\mathrm{ONOO}^{-}$produced during virus-induced inflammation may promote tissue injury in many ways.

Other important functions of $\mathrm{ONOO}^{-}$include the induction of apoptosis and necrosis, possibly via mitochondrial damage, which leads to cytochrome c release (Hortelano et al., 1999).

During viral and other microbial infections, NO is produced by iNOS in macrophages and phagocytic cells as an innate host response to the infectious agent. Studies with murine models on the molecular mechanism of iNOS activation revealed that several cytokines, including IFN- $\gamma$, TNF- $\alpha$, and IL-1, are responsible for this activation, with IFN- $\gamma$ playing the pivotal role (Drapier et al., 1988;
Xie et al., 1993). IFN- $\gamma$ is a cytokine of major importance for inducing iNOS and NO overproduction during viral infections (Zaki et al., 2005).

\section{Role of nitric oxide on influenza virus infection in mice}

As an effector molecule produced by phagocytic cells, NO has antiviral activity that is associated with nonspecific damage of host cells and tissues worsening the clinical course of viral infections. Therefore, in spite of the antiviral activity, excessive production of NO may facilitate viral pathogenesis (Zaki et al., 2005). This was demonstrated in a series of investigations on influenza virus infection in mice.

In 1996, Akaike et al. (1996) demonstrated that overproduction of $\mathrm{NO}$ in mouse lungs during influenza virus infection leads to the development of pneumonia. Both the enzymatic activity and mRNA expression of the iNOS were greatly increased in the mouse lungs, and it was mediated by IFN- $\gamma$. The time profile of iNOS induction in the lung correlated well with that of pulmonary consolidation rather than that of viral replication (iNOS expression began to increase on the 4th day after virus infection followed by rapid increment until 8 days after infection and diminished quickly thereafter). To establish the occurrence of NO overproduction directly in the mouse lung after infection with influenza virus, lung tissue was analyzed via ESR spectroscopy with a dithiocarbamate and iron complex as a spin trap for NO. Inhibition of NO by $N^{\oplus}$-monomethyl-L-arginine (L-NMMA) treatment of the influenza virus-infected mice resulted in significant improvement of the survival rate. Immunohistochemistry with a specific anti3-nitrotyrosine antibody showed intense staining of alveolar phagocytic cells, such as macrophages and neutrophils, and intraalveolar exudate in the virus-infected lung. 3-Nitrotyrosine formation as a consequence of peroxynitrite caused protein nitration thus indicating generation of peroxynitrite in the pathological process of influenza virus-induced pneumonia (Akaike et al., 1996).

NO-mediated pathogenesis of viral pneumonia was further investigated using genetically deficient iNOS $^{-1-}$ mice. The results revealed that influenza virus infection of the wild-type $\left(\mathrm{iNOS}^{+/+}\right)$mice increased NO levels in the bronchoalveolar lavage fluid and led to high mortality apparently because 
of the associated consolidating pneumonitis with massive inflammatory foci and edema within the lungs. The mice lacking the iNOS gene survived with little histopathologic evidence of pneumonitis (Karupiah et al., 1998).

Protein nitration as indicated by formation of 3 -nitrotyrosine is not the only marker of nitrative stress occurring during viral infections (Zaki et al., 2005). In 2003, Akaike et al. reported NO-dependent nucleic acid damage during viral infection in vivo with guanosine nitration and 8-nitroguanosine formation. Wild-type mice and mice deficient in iNOS were infected with influenza or Sendai virus. Formation of 8-nitroguanosine in the virus-infected lungs was assessed immunohistochemically with an antibody specific for 8-nitroguanosine. The most intense immunostaining for 8-nitroguanosine was detected in bronchial and bronchiolar epithelial cells at 6-8 days post infection. The staining was lighter in alveolar macrophages. The time profile of 8 -nitroguanosine production correlated well with that of $\mathrm{NO}$ production and 3-nitrotyrosine generation during influenza virus infection. Moreover, the 8-nitroguanosine staining colocalized with iNOS immunostaining and was absent in the airways of iNOS $^{-/-}$mice infected with influenza virus. A significant improvement of the survival as well as reduced pathological change in the lung was found in both iNOS ${ }^{-/}$and $\mathrm{iNOS}^{+-}$ mice compared with iNOS ${ }^{+/+}$mice. iNOS $^{+/+}$mice infected with influenza virus or Sendai virus had extensive inflammatory cell infiltration and alveolar exudates as well as destruction of pulmonary architecture, whereas in the iNOS $^{-/-}$mice these changes were significantly less. It is noteworthy that 8-nitroguanosine markedly stimulates $\mathrm{O}_{2}^{-}$ generation from cytochrome $\mathrm{P} 450$ reductase and iNOS in vitro (De Jong et al., 2006).

The enhanced antiviral antibody secretion and attenuated immunopathology during influenza virus infection was also reported in the study with iNOS-deficient mice (Jayasekera et al., 2006). The data of this investigation suggest that an increased virus-specific antibody response, rather than an enhanced cytotoxic T-cell response, may account for the reduced susceptibility of iNOS $^{-1-}$ mice to influenza A virus infection. Previous studies have demonstrated that influenza $A$ virus replication is sensitive to CD8+ T cell-mediated cytolysis, NKcell effector activity and the presence of virus-spe- cific antibody (Bender et al., 1992; Mozdzanowska et al., 1997; Stein-Streilein, Guffee, 1986). Each of these components of the immune response during infection of iNOS ${ }^{-/}$mice with a sublethal dose of virulent influenza $A$ virus was examined in this study. Both influenza A virus specific CD8+ Tcell and NK-cell cytolytic activities were similar in $\mathrm{iNOS}^{-/-}$and $\mathrm{iNOS}^{+/+}$mice. Thus, the T-cell and NK-cell cytotoxic responses do not contribute to the increased viral clearance in $\mathrm{iNOS}^{-/-}$mice. However, the virus-infected iNOS $^{-/-}$mice produced higher levels of virus-specific IgG2a antibody. Furthermore, more viable B cells and plasmablasts, along with greater levels of IFN- $\gamma$, were found in iNOS $^{-/}$splenocyte cultures stimulated with B-cell mitogens. $\mathrm{iNOS}^{-/-}$mice demonstrated a delay in manifestation of clinical illness and developed a statistically lower clinical illness score from day 7 of infection compared with iNOS ${ }^{+/+}$mice. Also, there was a significant attenuation in the extent of lung lesions in $\mathrm{iNOS}^{-/-}$mice. Inflammatory cell migration and proinflammatory cytokine production were attenuated significantly in the lungs of influenza A virus-infected $\mathrm{iNOS}^{-/}$mice. Importantly, this correlated directly with lower clinical illness and lung lesions observed in $\mathrm{iNOS}^{-/-}$mice, suggesting that iNOS exacerbates viral pneumonia by contributing to the recruitment of inflammatory leucocytes and to the prolonged expression of proinflammatory cytokines (Jayasekera et al., 2006).

In a recently performed study with mice, Aldridge et al. (2009) analyzed the new possibility for a new therapeutic intervention proposed for the case of a catastrophic pandemic. They showed that challenging mice with virulent influenza A viruses, including $\mathrm{H} 5 \mathrm{~N} 1$ strains, caused an increased selective accumulation of a particular dendritic cell subset, the TNF- $\alpha$ /iNOS-producing DCs (tipDC), in the pulmonary airways. However, although it might be expected that eliminating the tipDCs would ameliorate the disease process, the authors found the opposite phenomenon. The tipDCs also drive a local, protective $\mathrm{CD} 8^{+}$"killer" $\mathrm{T}$ cell response in the virus-infected respiratory tract. Most interestingly, this study established that partially compromising tipDC recruitment can be protective. Giving mice the peroxisome proliferator-activated receptor- $\gamma$ agonist pioglitazone diminishes but does not prevent tipDC recruitment, while allowing for sufficient $\mathrm{CD}^{+} \mathrm{T}$ cell expansion to protect against an 
otherwise lethal or at least highly pathogenic influenza virus challenge (Aldridge et al., 2009).

It is noteworthy that not only influenza virus infection causes pulmonary pathology associated with iNOS. Other pneumotropic viral infections are also responsible for NO induced damage of lung tissues. A study with herpes simplex virus type 1 (HSV-1)- induced pneumonia in mice was performed (Adler et al., 1997). Immunohistochemical staining demonstrated iNOS induction and the nitrotyrosine antigen in the lungs of infected, but not of uninfected mice, suggesting that NO contributes to the development of pneumonia. Infected mice treated with the NOS inhibitor, $\mathrm{N}^{\mathrm{G}}$-monomethyl-1arginine (1-NMMA), had less histological evidence of pneumonia, improved survival and pulmonary compliance of HSV-1 infected mice compared with those receiving placebo treatment, despite the presence of high pulmonary viral titers (Adler $\mathrm{H}$ et al., 1997).

Stark et al. (2005) examined the effect of respiratory syncytial virus (RSV) infection on expression of iNOS and the role of $\mathrm{NO}$ in the host responses to RSV in vivo. NO production, iNOS mRNA and protein levels were significantly increased in RSVinfected mice, and immunohistochemical analysis clearly identified iNOS in the respiratory epithelium. Suppression of NO synthesis using iNOS inhibitors increased RSV titers in the lungs, on the other hand, it reduced lung inflammation and RSV-induced airway hyper-responsiveness (Stark et al., 2005).

\section{Role of nitric oxide on influenza virus infection in humans}

Data about the implication of NO to the pathogenesis of influenza virus infection in humans are lacking. After the recent 2009 pandemics, more studies focused on human lung histopathology in the course of influenza A (H1N1) virus infection were performed, with greater attention paid to nitrative stress.

Increased NO and reactive oxygen species formation plays a critical role in lung dysfunction during acute lung injury and ARDS (Sittipunt et al., 2001; Kobayashi et al., 1998). Nin et al. (2012) analysed light microscopy findings as well as changes in the nitro-oxidative stress in lung tissue samples from pandemic 2009 influenza (A/H1N1) viral pneumonia and ARDS fatalities. Study specimens came from
6 intensive care unit patients with lethal $\mathrm{A} / \mathrm{H} 1 \mathrm{~N} 1$ influenza viral pneumonia. The most predominant pathological findings were diffuse alveolar damage, accompanied by hemorrhage in all cases and necrotizing bronchiolitis. All cases showed increased tyrosine nitration in the immunofluorescence studies, which indicates formation of peroxynitrite and subsequent protein nitration. The iNOS protein levels were increased in all cases. In addition, oxidized dihydroethidium staining, indicating the formation of oxygen free radicals, was increased in all cases. The increased oxidized dihydroethidium and nitrotyrosine reactivity were observed even in cases with prolonged ARDS, suggesting a role for prolonged oxidative and nitrative stress in the pathogenesis of ARDS in H1N1 influenza virus infection despite antiviral treatment. Other data from this study demonstrated viral proteins within macrophages and type I pneumocytes indicating they may remain in lung tissues for prolonged periods of time (Nin et al., 2012) and possibly participating in the prolongation of the inflammatory response.

In another study, a detailed histopathological analysis of the open lung biopsy specimens from five patients with ARDS with confirmed H1N1 was performed (Capelozzi et al., 2010). Lung specimens underwent microbiologic analysis and examination by optical and electron microscopy. Immunophenotyping was used to characterize macrophages, natural killer, $\mathrm{T}$ and $\mathrm{B}$ cells as well as the expression of cytokines and iNOS. Ultrastructural analysis showed viral-like particles in bronchiolar and alveolar epithelial cells in all cases. The main pathological findings revealed necrotizing bronchiolitis and diffuse alveolar damage; the altered respiratory epithelial cells probably served as the primary target of the infection. In these cases, expression in the lung of IFN- $\gamma$ by small mononucleated cells and TNF- $\alpha$ by macrophages and alveolar epithelial cells was low. Conversely, a very strong expression of IL-4, IL-10 and iNOS by macrophages was found. The results of this study indicate that in swine-origin influenza virus infection, altered innate and adaptive immune responses may lead to incomplete virus eradication in the primary target of the infection and, consequently, imbalance between inflammation and immune down-regulation resulting in bronchiolar obliteration and diffuse alveolar damage (Capelozzi et al., 2010). 
The nitrative stress during influenza infection may be evaluated not only by histopathological findings in the lungs, but also serologically. In 2011 Al-Nimer et al. (2011) evaluated the levels of NO and peroxynitrite in the serum of patients during seasonal and pandemic H1N1 infection. They found the greater levels of serum NO and peroxynitrite in patients infected with seasonal and pandemic H1N1 influenza as compared to the healthy control subjects. Although side-by-side comparisons may not be valid, it is interesting to note that the reported serum concentrations of reactive nitrogen species were higher in seasonal influenza patients than pandemic influenza patients.

\section{CONCLUSIONS}

Despite the differences between murine and human iNOS genes and their induction mechanisms, the evidence supports that infectious processes, including influenza, can trigger a nitrative stress in human lungs contributing to the pulmonary inflammation and tissue injury. More investigations need to be performed in order to extend our understanding on the role of reactive nitrogen oxides in inflammation and on the mechanisms that regulate iNOS expression, especially in human cells. This may offer new insights for the development of novel treatment of diseases complicated by increased iNOS expression and NO overproduction.

Received 14 April 2012

Accepted 19 May 2012

\section{References}

1. Abu-Soud HM, Stuehr DS. Nitric oxide synthases reveal a role for calmodulin in controlling electron transfer. Proc Natl Acad Sci USA 1993; 90: 10769-72.

2. Adler H, Beland JL, Del-Pan NC et al. Suppression of herpes simplex virus type 1 (HSV-1)-induced pneumonia in mice by inhibition of inducible nitric oxide synthase (iNOS, NOS2). J Exp Med 1997; 185: 1533-40.

3. Akaike T, Maeda H. Nitric oxide and virus infection. Immunol 2000; 101: 300-8.

4. Akaike T, Noguchi Y, Ijiri S, Setoguchi K, Suga M, Zheng YM et al. Pathogenesis of influenza virus- induced pneumonia: involvement of both nitric oxide and oxygen radicals. Proc Natl Acad Sci USA 1996; 93: 2448-53.

5. Akaike T, Okamoto S, Sawa T, Yoshitake J, Tamura F, Ichimori K et al. 8-Nitroguanosine formation in viral pneumonia and its implication for pathogenesis. Proc Natl Acad Sci USA 2003; 100: 685-90.

6. Aldridge JR, Moseley CE, Boltz DA, Negovetich NJ et al. TNF/iNOS-producing dendritic cells are the necessary evil of lethal influenza virus infection. PNAS 2009; 106(13): 5306-11.

7. Al-Nimer MSM, Mahmood MM, Khazaal SS. Nitrostative stress status during seasonal and pdmH1N1 infection in Iraq. J Infect Dev Ctries 2011; 5(12): 863-7.

8. Barnes PJ, Belvisi MG. Nitric oxide and lung disease. Thorax 1993; 48: 1034-43.

9. Bautista E, Chotpitayasunondh T, Gao Z, Harper SA, Shaw M, Uyeki TM et al. Clinical aspects of pandemic 2009 influenza A (H1N1) virus infection. N Engl J Med 2010; 362: 1708-19.

10. Belongia EA, Irving SA, Waring SC et al. Clinical characteristics and 30-day outcomes for influenza A 2009 (H1N1), 2008-2009 (H1N1), and 2007-2008 (H3N2) infections. JAMA 2010; 304: 1091-8.

11. Bender BS, Croghan T, Zhang L et al. Transgenic mice lacking class I major histocompatibility complex-restricted $\mathrm{T}$ cells have delayed viral clearance and increased mortality after influenza virus challenge. J Exp Med 1992; 175: 1143-5.

12. Bogdan C. Nitric oxide and the immune response. Nature Publishing Group http://immunol.nature. com 2001; 2(10): 907-16.

13. Capelozzi VL, Parra ER, Ximenes M, Bammann RH et al. Pathological and ultrastructural analysis of surgical lung biopsies in patients with swine-origin influenza type $\mathrm{A} / \mathrm{H} 1 \mathrm{~N} 1$ and acute respiratory failure. Clinics 2010; 65(12): 1229-37.

14. Chartrain N, Geller DA, Koty PP, Sitrin NF, Nussler AK, Hoffman EP, Billiar TR, Htchinson NI, Mudgett JS. Molecular cloning, structure, and chromosomal mapping of the human inducible nitric oxide synthase gene. J Biol Chem 1994; 269: 6765-72.

15. De Jong MD, Simmons CP, Thanh TT et al. Fatal outcome of human influenza A (H5N1) is associated with high viral load and hypercytokinemia. Nat Med 2006; 12(10): 1203-7. 
16. De Vera ME, Shapiro RA, Nussler AK et al. Transcriptional regulation of human inducible nitric oxide synthase (NOS2) gene by citokines: initial analysis of the human NOS2 promoter. Proc Natl Acad Sci USA 1996; 93: 1054-9.

17. Doi T, Ando M, Akaike T, Suga M, Sato K, Maeda H. Resistance to nitric oxide in Mycobacterium avium complex and its implication to pathogenesis. Infect Immun 1993; 61: 1980-9.

18. Domachovske JB, Bonville CA, Ali-Ahmad D, Dyer KD, Easton AJ, Rosenberg HF. Glucocorticoid administration accelerates mortality of pneumovirus-infected mice. J Infect Dis 2001; 184: 1518-23.

19. Drapier JC, Wietzerbin J, Hibbs JB. Interferongamma and tumor necrosis factor induce the Larginine-dependent cytotoxic effector mechanism in murine macrophages. Eur J Immunol 1988; 18: 1587-92.

20. Frears ER, Zhang Z, Blake DR et al. Inactivation of tissue inhibitor of metalloproteinase-1 by peroxynitrite. FEBS Lett 1996; 381: 21-4.

21. Förstermann U, Schmidt HH, Pollock JS et al. Isoforms of nitric oxide synthase: characterization and purification from different cell types. Biochem Pharmacol 1991; 42: 1849-57.

22. Gill J, Sheng ZM, Ely SF, Guinee DG, Beasley $\mathrm{MB}$ et al. Pulmonary pathologic findings of fatal 2009 Pandemic influenza A/H1N1 viral infections. Arch Pathol Lab Med 2010; 134: 235-43.

23. Guo Z, Shao L, Du Q, Park KS, Geller DA. Identification of a classic cytokine-induced enhancer upstream in the human iNOS promoter. Faseb J 2006; 21: 535-42.

24. Hobbs AJ, Ignarro LJ. The nitric oxide-cyclic GMP signal transduction system. In: Nitric oxide and the lung. WM Zapol, KD Bloch (eds.). New York: Marcel Dekker 1997: 1-57.

25. Hortelano S, Alvarez AM, Bosca L. Nitric oxide induces tyrosine nitration and release of cytochrome $c$ preceding an increase of mitochondrial transmembrane potential in macrophages. FASEB J 1999; 13: 2311-7.

26. Jacobs AT, Ignarro LJ. Lipopolysaccharide-induced expression of interferon- $\beta$ mediates the timing of inducible nitric-oxide synthase induction in RAW 264.7 macrophages. J Biol Chem 2001; 276: 47950-7.

27. James SL. Role of nitric oxide in parasitic infection. Microb Rev 1995; 59: 533-47.
28. Jayasekera JP, Vinuesa CG, Karupiah G, King NJC. Enhanced antiviral antibody secretion and attenuated immunopathology during influenza virus infection in nitritic oxide synthase-2-deficient mice. J Gen Virol 2006; 87: 3361-71.

29. Kačergius T, Ambrozaitis A. Contribution of nitric oxide to the pathogenesis of pulmonary infections (a review). Acta medica Lituanica 2003; 10: 16973.

30. Karupiah G, Chen JH, Mahalingam S, Nathan CF, MacMicking JD. Rapid interferon $\gamma$-dependent clearance of influenza A virus and protection from consolidating pneumonitis in nitric oxide synthase 2-deficient mice. J Exp Med 1998; 188: 1541-6.

31. Kash JC, Tumpey TM, Proll SC et al. Genomic analysis of increased host immune and cell death responses induced by 1918 influenza virus. Nature 2006; 443(7111): 578-81.

32. Klugman KP, Chien YW, Madhi SA. Pneumococcal pneumonia and influenza: a deadly combination. Vaccine 2009; 27(Suppl 3): C9-C14.

33. Kobayashi A, Hashimoto S, Kooguchi K et al. Expression of inducible nitric oxide synthase and inflammatory cytokines in alveolar macrophages of ARDS following sepsis. Chest 1998; 113: 1632-9.

34. Korhonen R, Lahti A, Kankaanranta H, Moilanen E. Nitric oxide production and signaling in inflammation. Current Drug Targets 2005; 4: 471-9.

35. Kuiken T, Taubenberger JK. The pathology of human influenza revisited. Vaccine 2008; 26(Suppl 4): D59-66.

36. Kuster SP, Tuite AR, Kwong JC, McGeer A, Fishman DN. Investigators TIBDN. Evaluation of seasonality of influenza and invasive pneumococcal disease: results from prospective surveillance. PLoS Med 2011; 8: e1001042.

37. Landino LM, Crews BC, Timmons MD, Morrow JD, Marnett LJ. Peroxynitrite, the coupling product of nitric oxide and superoxide, activates prostaglandin biosynthesis. Proc Natl Acad Sci USA 1996; 93: 15069-74.

38. Liew FY. Regulation of lymphocyte functions by nitric oxide. Curr Opin Immunol 1995; 7: 396-9.

39. Liu CY, Wang CH, Chen TC et al. Increased level of exhaled nitric oxide and up-regulation of inducible nitric oxide synthase in patients with primary lung cancer. Br J Cancer 1998; 78: 534-41. 
40. Lowenstein CJ, Alley EW, Raval P et al. Macrophage nitric oxide synthase gene: two upstream regions mediate induction by interferon $\gamma$ and lipopol and lipopolysaccharide. Proc Natl Acad Sci USA 1993; 90: 9730-4.

41. Marletta MA. Nitric oxide synthase structure and mechanism. J Biol Chem 1993; 268: 12231-4.

42. McCullers JA. Planning for an influenza pandemic: thinking beyond the virus. J Infect Dis 2008; 198(7): 945-7.

43. Moncada S, Palmer RM, Higgs EA. Nitric oxide physiology, pathophysiology and pharmacology. Pharmacol Rev 1991; 43: 109-42.

44. Moodley YP, Chetty R, Lalloo UG. Nitric oxide levels in exhaled air and inducible nitric oxide synthase immunolocalization in pulmonary sarcoidosis. Eur Respir J 1999; 14: 822-7.

45. Moreno JJ, Pryor WA. Inactivation of alpha 1-proteinase inhibitor by peroxynitrite. Chem Res Toxicol 1992; 5: 425-31.

46. Morens DM, Taubenberger JK, Fauci AS. Predominant role of bacterial pneumonia as a cause of death in pandemic influenza: implications for pandemic influenza preparedness. J Infect Dis 2008; 198(7): 962-70.

47. Morris SM, Billiar TR. New insights into the regulation of inducible nitric oxide synthesis. Am J Physiol 1994; 266: E829-39.

48. Mozdzanowska K, Furchner M, Maiese K et al. $\mathrm{CD} 4+\mathrm{T}$ cells are ineffective in clearing a pulmonary infection with influenza type $A$ virus in the absence of B cells. Virology 1997; 239: 217-25.

49. Muijsers RBR, ten Hacken NHT, Van Ark I, Folkerts G, Nijkamp FP, Postma DS. L-arginine is not the limiting factor for nitric oxide synthesis by human alveolar macrophages in vitro. Eur Respir J 2001; 18: 667-71.

50. Mulder J, Hers JFP. Influenza. Groningen, the Netherlands: Wolters-Noordhoff Publishing 1972: 287.

51. Nathan C, Xie QW. Nitric oxide synthases: roles, tools, and controls. Cell 1994; 78: 915-8.

52. Nathan CF, Hibbs JB. Role of nitric oxide synthesis in macrophage antimicrobial activity. Curr Opin Immunol 1991; 3: 65-70.

53. Nicholson S, Bonecini-Almeida Mda G, Lapa e Silva JR et al. Inducible nitric oxide synthase in pulmonary alveolar macrophages from patients with tuberculosis. J Exp Med 1996; 183: 2293302.
54. Nin N, Sanchez-Rodriguez C, Ver LS et al. Lung histopathological findings in fatal pandemic influenza A (H1N1). Med Intensiva 2012; 36(1): 24-31.

55. Okamoto T, Akaike T, Sawa T, Miyamoto Y, van der Vleit $\mathrm{A}$, Maeda $\mathrm{H}$. Activation of matrix metalloproteinases by peroxynitrite-induced protein S-glutathiolation via S-oxide formation. J Biol Chem 2001; 276: 29596-602.

56. Okamoto T, Akuta T, Tamura F, van der Vleit A, Akaike T. Molecular mechanism for activation and regulation of matrix metalloproteinases during infections and respiratory inflammation. Biol Chem 2004; 385: 997-1006.

57. Ricciardolo FL. Multiple roles of nitric oxide in the airways. Thorax 2003; 58: 175-82.

58. Rodriguez-Pascual F, Hausding M, Ihrig-Biedert I et al. Complex contribution of the 3'untranslated region to the expressional regulation of the human inducible nitric-oxide synthase gene: involvement of the RNA-binding protein HuR. J Biol Chem 2000; 275: 26040-9.

59. Saleh D, Barnes PJ, Giaid A. Increased production of the potent oxidant peroxynitrite in the lungs of patients with idiopathic pulmonary fibrosis. Am J Respir Crit Care Med 1997; 155: 1763-9.

60. Sawa T, Akaike T, Ichimori K, Akuta T, Kaneko K, Nakayama $\mathrm{H}$ et al. Superoxide generation mediated by 8 -nitroguanosine, a highly redox active nucleic acid derivate. Biochem Biophys Res Commun 2003; 311: 300-6.

61. Shanley TP, Zhao B, Macariola DR, Denenberg A, Salzman AL, Ward PA. Role of nitric oxide in acute lung inflammation: lessons learned from the inducible nitric oxide synthase knockout mouse. Crit Care Med 2002; 30: 1960-8.

62. Shiloh MU, MacMicking JD, Nicholson $S$ et al. Phenotype of mice and macrophage deficient in both phagocyte oxidase and inducible nitric oxide synthase. Immunity 1999; 10: 29-38.

63. Simonsen L, Clarke MJ, Schonberger LB, Arden NH, Cox NJ, Fukuda K. Pandemic versus epidemic influenza mortality: a pattern of changing age distribution. J Infect Dis 1998; 178: 53-60.

64. Sittipunt C, Steinberg KP, Ruzinski JT et al. Nitric oxide and nitrotyrosine in the lungs of patients with acute respiratory distress syndrome. Am J Respir Crit Care Med 2001; 163: 503-10.

65. Stark JM, Khan AM, Chiappetta CL, Xue H, Alcorn JL, Colasurdo GN. Immune and functional 
role of nitric oxide in a mouse model of respiratory syncytial virus infection. JID 2005; 191: 387-95.

66. Stein-Streilein J, Guffee J. In vivo treatment of mice and hamsters with antibodies to asialo GM1 increases morbidity and mortality to pulmonary influenza infection. J Immunol 1986; 136: 143541.

67. Suliman HB, Ryan LK, Bishop L, Folz RJ. Prevention of influenza-induced lung injury in mice overexpressing extracellular superoxide dismutase. Am J Physiol 2001; 280: L69-78.

68. Szabo C, Ischiropoulos H, Radi R. Peroxynitrite: biochemistry, pathophysiology and development of therapeutics. Nature Reviews 2007; 6: 662-80.

69. Tasher D, Stein M, Simões EA, Shohat T, Bromberg $\mathrm{M}$, Somekh E. Invasive bacterial infections in relation to influenza outbreaks, 2006-2010. Abstract. Clin Infect Dis 2011; 53: 1199-207.

70. Taubenberger JK, Morens DM. The pathology of influenza virus infections. Ann Rev Pathol 2008; 3 : 499-522.

71. Taylor BS, Geller DA. Molecular regulation of the human inducible nitric oxide synthase (iNOS) gene (review). Shock 2000; 13: 413-24.

72. Tracey WR, Xue C, Klinghofer V et al. Immunochemical detection of inducible NO synthase in human lung. Am J Physiol Lung Cell Mol Physiol 1994; 266: L722-7.

73. Turpeinen T, Nieminen R, Taimi V et al. Dual specificity phosphatase 1 regulates human inducible nitric oxide synthase expression by p38MAP kinase. Mediat Inflamm 2011; 2011: 1-15.

74. Uetani K, Der SD, Zamanian-Daryoush $M$ et al. Central role of double-stranded RNA-activated protein kinase in microbial induction of nitric oxide synthase. J Immunol 2000; 165: 988-96.

75. Umezawa K, Akaike T, Fuji S, Suga M, Setoguchi K, Ozawa A et al. Induction of nitric oxide synthesis and xanthine oxidase and their roles in the antimicrobial mechanism against Salmonella typhimurium infection in mice. Infect Immun 1997; 65: 2932-40.

76. World Health Organization. 2009. Influenza fact sheet No. 211 http://www.who.int/mediacentre/ factsheets/fs211/en/

77. Xie QW, Whisnant R, Nathan C. Promoter of the mouse gene encoding calcium-independent nitric oxide synthase confers inducibility by interferon gamma and bacterial lipopolysaccharide. J Exp Med 1993; 177: 1779-84.

78. Xiong Y, Karupiah G, Hogan SP, Foster PS, Ramsay AJ. Inhibition of allergic airway inflammation in mice lacking nitric oxide synthase 2. J Immunol 1999; 162: 445-52.

79. Zaki MH, Akuta T, Akaike T. Nitric oxide-induced nitrative stress involved in microbial pathogenesis. J Pharmacol Sci 2005; 98: 117-29.

\section{Birutė Zablockienė, Arvydas Ambrozaitis, Tomas Kačergius, Stefan Gravenstein}

\section{AZOTO OKSIDO REIKŠMĖ GRIPO INFEKCIJOS ATVEJU}

\section{Santrauka}

Gripo infekcija išlieka aktuali sveikatos problema visame pasaulyje dèl šios ligos sukeltų komplikacijų ir mirties atvejų. Dauguma mirčių gripo protrūkio metu būna susiję su virusinès ar bakterinès kilmès plaučių pažeidimu. Ištirta, kad plaučių pažeidimą sergant gripu sąlygoja laisvųjų radikalų, tokių kaip azoto oksido, pagausèjimas.

Straipsnyje apžvelgiama azoto oksido reikšmė pelių ir žmonių gripo infekcijos atveju, aptariami indukuojamos azoto oksido sintetazès aktyvavimo skirtumai žmonėms ir pelèms; taip pat aprašoma azoto oksido biosintezè, jo gaminimosi reguliavimas bei nitratinis stresas įvairių mikrobinių infekcijų metu.

Raktažodžiai: gripo viruso infekcija, azoto oksidas, indukuojama azoto oksido sintetazè 